\section{CONTEXTUAL EFFECTS OF CLASS MOBILITY ON VOTING BEHAVIOUR IN 16 WESTERN COUNTRIES: 1956-1990}

\author{
by
}

Paul Nieuwbeerta

(Department of Soclology, Utrecht Unjversity, Hejdelberglaan 1 ,
3564 CS Utrecht, Netherlands; email socw68 6 fswel fsw.ruunil)

Resume - Los effets de contexte prodults par mobilite soctale sur le vote dens 16 payn la mobllite soctale sur le vote de membres de classes intergénérationnellement contexte prodults par concernent les effets de niveau des entrees et des sorties d'une classe sociale specifiée (pour un pays et une année donnés). Ces hypothéses sont testées par une analyse multt-ntveau concemant des dornées sur 20.169 repondants issus de 113 enquetes faltes dans 16 pays démocratiques industrialisés pendant la pertade au nlveau des entrees, solt au ntveau des sorties instergontrent aucun effet de contexte significatif. pays, sur le comportement de vote des personnes intergenerationenes.llement mobilite soctale dans un discussion, l'auteur présente des explications posstbles pour ces résultats nèt immobles. Dans la niveau, Comportement de vote, Mobillte nocinle, Efrets de conterto.

Abetract. The author tests several hypotheses about the contextual effects of class mobility on the levels bhavour of intergenerallonally slable class members. These hypotheses pertain to the effects of year). The hypotheses are tested by multillevel modelling and ans (in a certain nation and a specific year. 113 hypotheses are tested by mult-level modelling, and analyzing data on 20.619 respondents
from 113 susveys held in sixteen industrialized democratic countres in the pertod $1956-1990$. Despite these efforts, the analyses show no significant contextual effect of either the level of intergenerational inflow or the level of outflow social mobility in a country on the voting behaviour of intergeneratlonally immoblle persons. In the discussion section posstble explanations for these negative results are
discussed. Multilevel Analyne, Voting Bohaviour, Social Mobulty, Context Effecta.

\section{INTRODUCTION}

In almost all democracies, socio-economic class is a prime determinant of voting behaviour. Persons in the lower classes have a higher chance of voting for a left-wing political party than the higher classes (Alford 1963; Heath et al. 1985, 1995; Nieuwbeerta 1996).

However, to understand fully the relationship between class position and voting behaviour one has to take into account that socio- economic classes in the advanced industrial societies are far from homogeneous and static. In all Western countries people move up and down the social ladder with respect to their father. Occupational groupings or class in modern society, therefore, may be envisaged as comprising two different elements: one a more or less permanent "core", 1.e. the intergenerational immobile, the other made up of moblle individuals of relatively recent membership, i.e. the intergenerationally mobile - those who climbed up or down the social ladder with regard to their parents. Processes of social mobility, therefore, may help to explain "class-deviant" behaviour within a country (Abramson, 1972) or, since patterns of absolute intergenerational class mobility differ between countries and periods (Erikson \& Goldthorpe 1992), to explain cross-national or over-time varlations in levels of class voting (De Graaf \& Ultee 1990; Nieuwbeerta 1995).

When examining the relationship between intergenerational class mobility and individual voting behaviour, most researchers have adopted the micro-sociological perspective, l.e. they have investigated the effects of individual moblity on the voting behaviour of intergenerationally mobile persons (see for example: Barber 1970; Weakliem 1992; Nieuwbeerta \& De Graaf 1993; De Graaf et at. 1995). A series of studies stretching from the first to the third generation of research on stratification and politics (Nieuwbeerta 1995), however, suggests that intergenerational class mobility may also influence people's voting behaviour in a more indirect way, i.e. people may change their voting behaviour because they perceive intergenerational class mobility in their environment (Lipset 1960: Blau \& Duncan 1967; Abramson \& Books 1971; Thorburn 1979; Goldthorpe 1986). It are these "contextual effects" of class mobility that we focus on in this paper.

Although, of course, such contextual effects can be assumed to affect the voting behaviour of both the intergenerationally mobile and the immobile, we restrict our investigations to the immobile class members. We do this, because for the Immobile the contextual effects can be expected to be stronger than for the mobile. The contexts of mobile have changed over their life course and consequently they were subject to conflicting contextual effects. However, for immobile class members contextual effect are easier to detect. In this paper we thus address the question: What are the contextual effects of intergenerational class mobility in a country on the voting behaviour of intergenerationally immobile persons?

Addressing this questions, we build on hypotheses and results of many earlier studies, but aim to make progress in various ways. So far, many scholars have formulated theories and hypotheses about the effects of social mobility in people's context on their political 
preferences (for example: Thorburn, 1979; Abramson \& Books, 1971), but only few empirical research has been done to test whether such effects of contextual soctal mobility could be detected. Furthermore, the research on this topic that has been done, deals with only a small number of contexts and inadequate done, deals (e.g. Thorburn 1979). In this contexts and inadequate techniques (e.g. Thorburn 1979). In this paper we aim to make progress by analyzing a dataset containing information of individuals in many different contexts, 1.e. in seven distinguished social classes in sixteen countries and several years over the period 1956-1990. Furthermore, we use multi-level models which are especially designed to investigate contextual effects.

\section{HYPOTHESES}

Many scholars of the various generations of research on stratification and politics have formulated theories and hypotheses about the contextual effects of class mobility on voting behaviour (for example: Blau \& Duncan 1967: 440; Abramson \& Books 1971; Thorburn 1979; De Graaf \& Ultee 1987). Building on this 1971; research into the contextual effects of hypotheses about the effects of two characteristics of mobility patterns on the voting behaviour of immobile class members. These characteristics are the level of outflow mobility from a specific class and the level of inflow mobility to a specific class.

To hypothesize on the effects of levels of outflow and inflow mobility in a certain class on the voting behaviour of the members of that class, we use the instrumental and expressive theories of individual voting behaviour (see also: Heath et al 1995: 999). is rational and self-interested: people vote according to their interests and therefore vote for the party whose policies will bring them the greatest utility now or in the furse policies will bring theory, voting is seen as a social act rather the one. People associate with each other thought to provide an are influenced in which voting behaviour may be influenced. in general, such associations are made with people from the same class position, but sometimes - for example due to class
mobility - they are not.

An hypothesis concerning the effects of the level of inflow mobility to a class on the voting behaviour of the stable members of that class. can best be deduced from the class. cexpressive theory. Because people in general associate with people occupying the same class position Goldthorpe 1986), people's alignments to a certain party are usually stimulated by the influences of their class co-members, and all influences being in the same direction. However, when classes are heterogeneous - due to the inflow of intergenerationally mobile people - we would expect the existing mobile class members to be influenced by the different voting behaviour of those entering the class. This is espectally the case when the influx of newcomers with different political attttudes and behaviours is large (see also Lipset 1960):

The impact of newcomers may be expected to depend not only on the amount of inflow to a class, but also on the political character of that inflow. The more left-wing the voting behaviour of newly arrived class members, the more will the voting behaviour of the stable class members be left-wing. Thus, the effects of inflow mobility on the voting behaviour of immobile class members can be assumed to be dependent on two factors: the absolute level of inflow mobility to a class, and the political character of this inflow. Therefore, the following inflow mobility hypothesis can be formulated: The higher the level of left-wing inflow mobility to a class, the more likely it is that the immobile members of that class will vote for a left-wing. political party.

The effects of the level of outflow mobility from a class on the individual voting behaviour of immobile members of that class, can be deduced from the instrumental theory. We might expect that people are influenced by seeing others move out of their class. If people see many co-class members leaving their class, they can be expected to anticipate the possibility of mobility for themselves. Consequently, they might adjust their voting behaviour in line with possible future interests. It is through this mechanism that the level of outflow mobility from a class can be expected to have an effect on the voting behaviour of immobile members of that class.

Agatn, it should be noted that the effects of outflow mobility on the voting behaviour of immobile class members depend upon two factors. The first is the absolute level of outflow mobility, i.e. the percentage of class members leaving the class of their father. The higher the amount of outflow mobility from a class, the greater the likelihood that immoblle class members will change their voting behaviour. The second factor, the political character of the outflow mobility - i.e. the interests and typical voting behaviour of the classes where the mobile flow to - can also be assumed to have an impact on the voting behaviour of those who are "left behind". The more left-wing the interests of those moving out become, the more those who stay in their class will anticipate these new interests and consequently vote in a more left-wing way. Summarizing these arguments leads us to the following outflow mobility hypothesis: The higher the level of left-wing outflow mobility from a class, the more 
likely it is that the immobile members of that class will vote for a leftwing political party.

The implications of this hypothesis can best be illustrated by an example. For instance, immobile unskilled manual workers in a society with a high level of outflow from their class, might anticipate their own possible mobility. Because, by definition, those moving out go to classes with less left-wing interests, the immobile unskilled manual workers may adopt a less left-wing political party preference than they would have adopted in a society with little outflow from their class. This hypothesis is directly in line with Blau and Duncan's argument that "men who see little opportunity for improvement in their own economic status or, at least, that of their children, have greater inducernents than those anticipating advancements in status to organize a union, to raise wages or to vote for a party that advocates higher taxes for the wealthy" (1967: $440)$.

However, the effect of the amount of outflow mobtlity from the unskilled manual class does not give sufficient information about the direction and the extent to which the immobile class members are influenced by level of outflow mobtlity. This depends on the classes to which the moblle members go. For example, in a country where most people from the unskilled manual class go to the skilled manual class (with its similar interests and voting behaviour), the voting behaviour of the immobile members of the unskilled manual class will hardly be affected by the level of outflow from their class. Conversely, in a country where most of those leaving the unskilled manual class go to the service class (which has less to gain from a more egalitarian society and displays, in general, a substantially less left-wing voting pattern), it is likely that the voting behaviour of the immobile members of the unskilled manual class will change substantially. Similarly, for members of the other social classes it can be hypothesized that the more they see their class members fall down the social ladder, the more they will anticipate their own downward mobllity, and thus vote in a more left-wing way.

Before testing the formulated hypotheses, we should first note a conflicting argumentation that has also been suggested in the literature. Goldthorpe (1986: 342), for example, suggested such an hypothesis on the basis of social-psychological arguments. He argued that the more men of working class origins make their way into the service class, the more it would seem reasonable to suppose that a large majority of those who remain within the working class will "have a recognition of apparent 'openness'". Consequently, among those who - so to speak - were "left behind", some degree of discontentment or frustration might develop. Then, under the assumption that dissatisfaction and frustration for manual class members lead to a more left-wing voting behaviour, it can be expected that those who stay behind vote more left-wing than they expected that those who stay behind vote more left-wing than they people were upwardly mobile from their class. However, Goldthorpe people were would not be widespread due to the fact that for those who fail to achieve upward whello mobility, there still remain many alternatives that can serve to hypotheses this argumentation has to be kept in mind.

\section{DATA AND OPERATIONALIZATIONS}

While questions at the individual-level in principle can be addressed While questions at the from a single country and year, in the case of using a single dater number of contexts the better. For this reason, we employ a data file containing individual-level data from sixteen OECD countries, seven classes and many years over the period 1956-1990. The countries involved are: Australia, Austria, Belgium, Britain, Canada, Denmark, Finland, France, Germany, Ireland, Italy, the Netherlands, Norway, Sweden, Germany, Ireland, Italy, the Netheritzerland, and the United States. Because of our research Switzerland, and the United States. Because of our research male members of the classes aged eighteen years or older, leaving us with a total of 20,619 respondents. By analyzing data on so many contexts and so many individuals we aim to give hypotheses on the contextual effects of class mobility a higher chance of corroboration in empirical tests, than has been the case in earlier studies. More information on the data file used is given in Appendix A.

To measure respondent's class position, we utilized the seven class version of a class scheme orfinally introduced by Goldthorpe for the Oxford Mobility Inquiry (Goldthorpe et al. 1978) and later elaborated by Erikson, Goldthorpe, and Portocarrero (1979) and Erikson and Goldthorpe (1992). In this scheme, for brevity's sake called EGP class scheme, individuals are categorized into a class based on their sector, self-employment status, and supervisory status. The EGP class scheme has been useful in comparative studies of intergenerational class mobility (Ganzeboom et al. 1989; Erikson \& int in studies examining the relationship Goldthorpe 1992), and in studies examining the between social class and voting behaviour (Heath et al. 1985, Evans et al. 1991; Nieuwbeerta 1995). Furthermore, this scheme is applied in analyses of the effects of individual class mobility on voting behaviour in single countries (Nieuwbeerta \& De Graaf 1993 Clifford \& Heath 1993) as well as in international comparative studies (De Graaf et al. 1995: Nieuwbeerta 1995). 
The seven class version of the EGP class scheme distinguishes between the class categories given in Table 1. Respondents were coded into the EGP classes on the basis of data on their occupation, self-employment and supervisory status. Two steps were involved. First, the original occupation codes were recoded into the International Standard Classification of Occupation (ISCO) codes (ILO 1969). Second, these ISCO codes were translated into EGPscores through the Ganzeboom, Luijkx and Treiman (1989) recoding scheme.

To measure voting behaviour of class members, it would be preferable to have data on the actual voting behaviour of respondents during specific elections in the surveys. However, because voting is confidential in democratic countries, we have to rely on indirect measures of voting behaviour. In the surveys employed various such indirect measures are used as indicators for respondent's voting behaviour. In some surveys respondents were asked to name the political party they would vote for if there were a national election tomorrow. In other surveys respondents were asked to name the party they voted for at the most recent national election. In yet others respondents were asked which political party they preferred or identified with. The limitations introduced by such different measures of voting behaviour must be fully appreciated. However, various analyses using only surveys containing "voting behaviour" measures, and several analyses using only surveys containing "political preference" measures, did not result in different outcomes. Thus, we are confident that using these different measures of voting behaviour in the analyses does not cause major problems. Indeed, we know of no study showing that the relationship between class and political preference is fundamentally different from that between class and respondent's voting behaviour.

In order to produce a classification of parties voted for that would allow cross-country comparison, we followed Bartolint \& Mair (1990) and Franklin and his colleagues (1992), and dichotomized the political parties into left-wing on the one side and right-wing on the other. In deciding whether a specific party should be included in the left-wing block, we followed the criteria given by Bartolini \& Mair (1990: 42-43), and defined "all those socialist parties which are members of the Soctalist International and of all those communtst parties which were once members of the Communist Third International" as left-wing parties. Since according to these criterta hardly any left-wing voters would exist in the United States, for that country an exception to the criteria was made, and the Democratic Party was defined as left-wing party.

\section{MODELLING CONTEXTUAL EFFECTS OF CLASS MOBILITY}

The main thrust of our contextual hypotheses is that the voting The main thrust of our conte members of a particular class in a behaviour of individual stable members of a particular class in a certain country for a given year, can be explained by the inflow and testing the hypotheses we have to take account of the layered testing the hypotheses we have to take account of the lay structure of our data, i.e. Indives An appropriate way to test ou within classes and countries. An approprate way to test our hypotheses is to use a mult-level model containing three different class/country-level.

When modelling these effects two remarks are in order. First. the effects of inflow and outflow mobility depend both on the amount of inflow and outflow mobility and on the political character of that inflow and outflow. However, the amount of inflow and outflow inflow and outhow. do not give an indication of the direction in which mobility per se, do not give will change their voting behaviour, i.e. the immobile class members will change their or more left-wing. whether they will become more right-wing or more leftwing. Therefore, in our modeis we take this into account by including interaction effects of the level of inflow and political character of that inflow and outflow.

A second consideration when testing the contextual effects of class A second on the individual voting behaviour of intergenerationally mobllty on the thetring behaviour is not solely affected by differences in rates of inflow and outflow mobility, but affected by differences in rates of interests. are more determined by their material clrcumstances and interests. We take this into account in our modelling by allowing each class within each nation to have its own "natural": level of left-wing within each nathences. In this way we can test whether rates of outflow and preferences. In this way for vartations around this natural level.

Therefore, to test the hypotheses concerning the effects of levels of inflow and outflow mobility in a society on individual voting inflow and outflow mobilty models that take these considerations behaviour we use multi-level models that the inflow mobility into account. We use three models: one that tests the infow mobis, and one hypothesis, one that tests the outflow mobility hypothesis, and one that tests both these hypotheses simultaneously. In all three models, at the individual-level we estimate the voting behaviour of individual immobile class members as follows:

$\log \left(\left(\mathrm{O}^{*} \operatorname{Left}_{\mathrm{idjk}}\right) /\left(1-\mathrm{O}^{*} \operatorname{Left}_{\text {ddjk }}\right)\right)=\beta_{0 \mathrm{djk}}+Y_{\text {idjk }}$ 
In this individual-level equation, the dependent variable is the logodds for the immobile members (i) of each class (d) to vole the logwing political party rather than a right-wing party in each year (j) and country $(\mathrm{k})$. The intercept in the individual-level equation, $\beta_{0}$ djk. represents the mean log-odds of voting left-wing rather right-wing for stable class members in each of the distinguished classes and countries in each year. This intercept (which an vary from year to year, from class to class, and from nation to nation), serves as the dependent variable in the year-level equation.

To test the inflow mobility hypothesis we then use a model (Model A) in which the year-level equation is specified as follows:

$\beta_{0 d j k}=\beta_{0 d 0 k}+\beta_{1000}\left(\right.$ Inflow $\left._{d j k}{ }^{*} I n-w_{e i g h t} d k\right)+y_{0 d j k}$

Similarly, to test the outflow mobility hypothesis we apply a model (Model B) with the following year-level equation:

$\beta_{0 d j k}=\beta_{0 d 0 k}+\beta_{2000}\left(O_{\text {utflow }}{ }_{d j k}{ }^{*}\right.$ Out-weight $\left.t_{d k}\right)+y_{0 d j k}$

In addition, to test the inflow and outflow hypotheses simultaneously, a third model (Model C) will be applied, whereby the year-level equation reads as follows:

$\beta_{O d j k}=\beta_{0 d O k}+\beta_{1000}\left(\right.$ Inflow $_{d j k}{ }^{*}$ In-weight dk $\left._{k}\right)+$

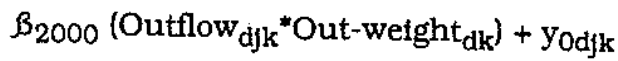

In these equations the variable Inflow djk represents the proportion of class $d$ in year $j$ and country $k$ who were intergenerationally mobile (that is, who came from non-d origins). The variable oufflow represents the proportion of class $d$ in year $j$ and country $k$ who were intergenerationally mobile (that is, who went to non-d destinations). The variables In-weight $\mathrm{dk}_{\mathrm{dk}}$ and Out-weight $\mathrm{dk}_{\mathrm{k}}$ stand for the weight factors that take into account the political character of the outflow mobility to and inflow mobility from a class in a country.

In all three models, the combined explanatory variables are centred around their grand mean in each class and each nation. Therefore, $\beta_{\text {odok }}$ represents the natural left-wing voting behaviour in the different classes in each country. To allow this natural level to vary from class to class and from nation to nation. $\beta_{0 \text { OdOk }}$ is treated as random at the class/country-level:

$\beta_{0 \mathrm{dOk}}=\beta_{0000}+\dot{U}_{0 \mathrm{dOk}}$

To calculate the political character of the inflow and outflow mobility, In-weight behaviour of the stable members of the origin classes in our dataset (cf. De Graaf et al. 1995). These weights must be kept constant overtime, since allowing them to vary each year could introduce circularity into the model. This is because in some years, quite independent of levels of mobility, there may be across-the-board increases in left-wing voting behaviour affecting the mobile and the stable alike. Weights which were allowed to vary each year might thus be correlated with the yearly variations in the dependent variable.

A numerical example may make clearer the procedure for calculating the political character of the inflow and outflow mobility. In calculating the political character of the inflow mobility to the service class in Britain in 1964, we first take the actual proportions of the service class in Britain in 1964 who moved from the other six classes. Of these, 20 per cent originated in the unskilled manual class. This figure is then weighted by 0.61 (the proportion of the stable members of the unskilled manual class who had a left-wing voting behaviour in Britain in the combined British dataset). Similarly, the 4 per cent who were mobile from the agricultural worker class is weighted by 0.41 . The weighted inflow to the service class in Britain in 1964 thus becomes $\left(20^{*} 61+28^{*} 61+4^{*} 41+7^{*} 33\right.$ $\left.+11^{*} 11+4^{*} 8\right) / 100$, or 34.8 . The calculation of the left-wing inflow mobility for other classes and countries proceeds in an analogous manner. In calculating the left-wing outflow mobility we follow the same procedure, except that here we weight by the proportion and the voting behaviour of the destination classes. 


\section{RESULTS: TESTS OF CONTEXTUAL HYPOTHESES}

We now test the formulated contextual hypotheses. The first hypothesis, the outflow mobllity hypothesis states that the more "left-wing outflow" from a class there is, the more likely it is that stable members of that class will vote for a left-wing political party. The second hypothesis, the inflow mobility hypothesis, implies that the more left-wing inflow mobllity to a class there is, the more likely it is that stable members of that class will vote left-wing.

We test these hypotheses in four different ways. To begin with we test the hypotheses for all classes simultaneously. Next, we test them for each class separately. Subsequently we test the hypotheses focusing on the effects of "pure" inflow and outflow mobility, i.e. not controlling for the political character of the inflow and the outflow mobility. Fourth, we test the hypotheses examining the effects of "extreme" inflow and outflow mobility on the voting behaviour of the immoblle members of two classes that have very distinct interests, the unskilled manual.class and the servtce class.

\section{Tests: All Classes Simultaneously}

To test the hypotheses for all classes simultaneously, the three multi-level models are fitted on 20,619 respondents within 599 years within 107 country/class combinations. Model A tests the inflow mobility hypothesis, by including the interaction effect Inflow*In-weight as a contextual explanatory vartable. The outflow mobility hypothesis is tested by fitting Model $\mathrm{B}$, which includes the interaction effect Outflow*Out-wetght. In Model $\mathrm{C}$ the Inflow*Inweight and the Outflow*Out-weight vartables are included simultaneously. When the hypotheses hold, we expect the parameter estimates for these variables to be positive and significantly different from zero. The parameter estimates for the three fitted multi-level models are presented in Table 2 .

The estimates of the parameters in the multi-level analysis in Models $\mathrm{A}$ and $\mathrm{C}$, indicating the effect of left-wing inflow mobility are 0.004 and 0.005 respectively. These estimates are in the expected direction but clearly not statistically significant. We therefore can not accept the hypothesis that the more left-wing inflow mobility there is to a class, the more likeiy it is that immobile members will have a left-wing voting behaviour.

In Models $\mathrm{B}$ and $\mathrm{C}$ estimates of the effects of left-wing outflow mobility take the values -0.001 and -0.002 respectively. These are not in the expected direction, but are also not statistically significant. Therefore, we can not accept the outflow mobillty hypothesis that the more left-wing outflow mobllity there is from a hypothesis that the more likely it is that immobile members of that class will have a left-wing voting behaviour.

\section{Tests: Per Clase}

It might be, however, that while we must reject the inflow and outflow hypotheses for all classes simultaneously, they nevertheless outhow hypotheses for al come particular classes. For this reason hold for stable members of some particular classes. we fit our models for the stable mer each class separately, multiseparately. To test our hypotheses for each class separately, mult level models are fitted, each analyzing only those respondents who currently are members of a specific class. As in the test for all classes simultaneously, we ftt three models: Model A including the interaction effect Inflow*In-weight, Model B including the interaction interaction effect Inflow'In-weight, Model C including both these effect Outflow* Out-we the hypotheses hold, significant positfve variables. Again. if the hypotheses hold, significant post the
parameter estimates are to be expected. In Table 3 only the pertinent parameter estimates of the fitted multi-level models are coefficients - are not reported.

The results of these tests are largely negative. The figures in Table 3 The estimated parameters are statistically indicate that none of the estimated parameters are statistically significant. Furthermore, ten out of the twenty-eight estmated parameters have a negative value, the even when testing the unexpected direction. This means that even when testng the

hypotheses for all classes separa
hypotheses have to be rejected.

\section{Tests: Effects of "Pure" Inflow and Outflow Mobility}

Before drawing conclusions with respect to the inflow and outflow Before drawing conclusions wh in order. It might be argued that the hypotheses, an extra test is in order. It might be and of inflow and inclusion of interaction effects between the amount of inflow and outflow mobility and the political character of that mobility obscure the main effect of the level of inflow and outflow mobility. Therefore the main a check we do our analyses including only the pure mobility leve as a check we do our analyses including onls in models D, E and F variables in modeis $A$, $B$ and $C$. There the In-weight and Out-weight variables are left out. 
When making predictions about the effect of the pure levels of inflow and outflow on the voting behaviour of immobile members of specific classes, assumptions must be made about the political character of that inflow and outflow. For some classes it is easy to come up with predictions, because the assumptions are straightforward. For example, it can be assumed that all people who move out of the skilled and unskdlled manual classes go to classes with more rightwing interests and political culture than are found among the stable members of the manual classes. Thus, for members of the unskilled and sktlled manual classes, it can be expected that the more outflow from their class there is, the more right-wing they will be. Furthermore, it can be assumed that those who move into the manual classes also have more right-wing voting behaviour than the stable members of these classes. Therefore, it can be expected that the more inflow mobility there is to the manual classes, the less likely the immobile members of these classes will be to vote for a left-wing party.

In addition, for members of the farming and petty bourgeoisie classes it can be assumed that most outflow goes to more left-wing classes, while most inflow comes from more left-wing classes. In this way it can be predicted that the more inflow mobility to these classes, the more likely members of these classes are to vote leftwing. For the other classes - the service class, the routine nonmanual class and the agricultural labourers - making predictions about the effects of the amount of inflow and outflow mobility is less straightforward. The political character of that mobility depends too much on the patterns of intergenerational mobility in a country in a certain year to be able to predict the contextual effects of inflow and outflow mobility for these classes.

To test our predictions about the effects of pure inflow and outflow mobility on the voting behaviour of stable class members, we follow the same procedure as before. For each class separately, three multi-level models are fitted, each analyzing only those respondents who are members of a specific class. Model $D$ includes the Inflow variable, model $\mathrm{E}$ the Outflow variable, and model $\mathrm{F}$ includes both these variables. In Table 4 the pertinent parameter estimates are presented. Again the results of these tests are negative. None of the estimated parameters representing the effects of levels of inflow and outflow differ significantly from zero. Thus, in none of our analyses so far, did we find a single indication of a contextual effect of inflow and outflow mobility in a country on the voting behaviour of immobile class members. This gives us strong grounds on which to reject both hypotheses outright.

\section{Tests: Effects of "Extreme" Inflow and Outflow Mobility}

Although the resuits presented above seem convincing, we would like to perform one further analysis. When the scholars of the first generation hinted at the existence of contextual effects of class mobility, they had no detailed class scheme available or even in mind. Their claims about the existence of contextual effects referred mainly to simple ideas of inflow and outflow mobility from the highest to the lowest classes (see for example: Abramson \& Books 1971, and Parkin 1971) To do justice to these claims, we therefore do a last test where we focus on the effects of inflow and outflow mobility on the voting behaviour of members of two classes that are "extreme" with respect to their interests, the service class and the unskilled manual class. We carry out separate analyses for both of these classes, and focus on the effects of inflow and outflow mobility from one of these classes to the other. Of course, the idea behind these analyses is that, if contextual effects do exist, these can be expected to be detected most easily when investigating the effects of this "extreme" inflow and outflow mobility.

On the basis of our above formulated hypotheses and earlier studies on this topic, we can expect the level of inflow mobility from the unskilled manual class into the service class to have a significant effect on the voting behaviour of immobile class members of the service class. The more former members of the unskilled manual class enter the service class, the more the stable members of the service class will be influenced by them, and consequently the more they will vote for a left-wing rather than a right-wing political party. Similarly, we expect the level of inflow mobility from the service class into the unskilled manual class to have a substantial impact on the voting behaviour of the stable members of the unskilled manual class. The more service class members move into the manual class, the more the members of that manual class can be expected to vote for a right-wing party.

In addition, we can formulate hypotheses concerning the effects of levels of outflow mobility. If stable members of the service class see many of their class members "fall" to the unskdlled manual class, it can be expected that the stable service class members anticipate their own downward mobility and thus become more likely to vote for a left-wing party. Thus, the more outflow mobility from the service class into the unskilled manual class, the more the stable members will vote for a left-wing party. Again, an analogous idea can be applied to the voting behaviour of the stable members of the unskilled manual class. In this case, it can be expected that the more people from the unskilled manual class climb to the service 
class, the more those who remain in the unsklled manual class will anticipate their own climb, and the more they will vote right-wing.

To test the hypotheses of "extreme" inflow and outflow mobllity, we first do a separate analysis on data from stable members of the service class. We use the same models and data as earlier, but as our explanatory Inflow variable we take of the total number of people currently in the service class the percentage that arrived into the service class from the unskilled manual class. Furthermore, we take the percentage of people who moved into the unskilled manual class, based on the total number of people that were originally members of the service class, as the Outflow variable. Again we fit three models, one including as an explanatory variable only the Inflow variable, a second only the Outflow variable, and a third both variables. The results of fitting these models to our data, however, show statistically insignificant parameter estimates for these explanatory variables. The parameter of the Inflow variable has the value of -0.001 (s.e. 0.014 ) when it is solely included, and 0.002 (s.e. 0.014 ) when it is simultaneously included. In addition, the Outflow parameters ydeld the value -0.012 (s.e. 0.019) and -0.013 (s.e. 0.020 ), respectively.

A separate analysis, using the same model and data, but now concerning the voting behaviour of the stable members of the unskilled manual class also yields statistically insignificant parameter estimates. As our Inflow variable we take the percentage of the total number of people currently in the skilled manual class, that arrived into the skilled manual class from the service class. As our Outflow variable we take the percentage of people who moved into the service class, based on the total number of people who were originally members of the unskilled manual class. The parameter estimate of the Inflow variable has the value 0.002 (s.e. 0.012 ) when it is solely included, and -0.002 (s.e. 0.014) when it is simultaneously included. The Outflow parameter estimates yleld the values -0.003 (s.e. 0.024 ) and 0.011 (s.e. 0.022 ) respectively.

Thus, also dotng these analyses on "extreme" inflow and outflow mobiltty, we do not find any corroboration of the hypotheses concerning the contextual effects of inflow and outflow class mobility on the voting behaviour of immobile class members.

\section{CONCLUSIONS}

In studies of the first until the third generation of research on stratification and politics many scholars have suggested that intergenerational class mobility has contextual effects on the voting behaviour of stable class members. However, such arguments have been made without the support of empirical evidence. In this paper we used the literature to formulate two hypotheses about the contextual effects of class mobllity on the voting behaviour of intergenerationally immobile class members. These hypotheses pertain to the effects of both inflow mobility and outflow mobility. We aimed to make progress on earlier studies of research on stratufication and politics by giving the hypotheses the highest possible chance to be corroborated. First, we tested these hypotheses by analyzing survey data from a very large number of contexts, i.e. data of seven classes from sixteen countries over the period 1956 to 1990 . Second, we used multi-level models which are especially designed to investigate contextual effects. Despite these efforts the results were negative. The analyses showed no significant contextual effect of either the level of intergenerational inflow or the level of outflow class mobility in a country on the voting behaviour of intergenerationally immobile persons. These negative results are remarkable when regarding the large number of studies that have suggested the contextual effects of intergenerational class mobility on politics.

An explanation for the negative results might be the number of contexts under investigation in this paper. We realize that. due to

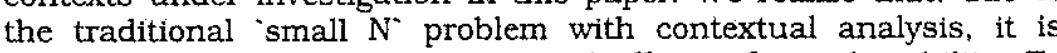
difficult to find significant contextual effects of social mobility. To find statistically significant effects of contextual variables, a change of one percent in the amount of mobility has to lead to a rather large change in the percentage of people that have a left-wing voting behaviour. On the other hand, by analyzing data from more than twenty-thousand individuals in seven classes from 16 countries interviewed in several years, we have given the hypotheses on the contextual effects of class mobility a significant. higher chance of corroboration in empirical tests, than has been the case in earlier studies. Even more, from a practical point of view it is almost impossible to find data of intergenerationally immobile respondents from more countries and years.

A more substantive explanation for the negative results might be that there is a difference between perceived and actual levels of mobility in a class. The perceived level of mobility may largely be influenced by local examples that do not necessarily represent the influenced by local examples that do not necessarily represent the
national mobility pattern. This is an important issue, since we might expect class members' perceptions of potential mobility to have a larger influence on their political party preferences. Another explanation, linked to the first, might be that perceived mobility chances may not be based upon long range mobility. In our analyses we only investigate inter-class mobility. However, people also change in social positions within classes, for example people change in their 
income position. Thus, it might be that if class members think about their chances of becoming upwardly or downwardly mobile, they think more in terms of intra-class mobility than inter-class mobility. If this is the case, even our detailed EGP class is still to because it does not allow us to pick up the contextual effects of intra-class income mobility. Concluding, a rephrasing of the hypotheses in terms of the contextual effects of local short-range mobility on individual voting behaviour, seems worthwhile.

The negative results in this paper have consequences for understanding the political consequences of mobility on the political constellation in a country. In earlier studies, it has been customary to concentrate on the mobile and to suppose that more (upward) mobility in a country leads to a lower level of class voting in that country. Such arguments generally assume composition effects. For example, if more people with manual backgrounds enter the service class, its mean voting behaviour will be more left-wing. However, also contextual effects of social mobility are generally assumed to strengthen a shift to less class voting. For instance, the influences of the mobile members on the immobile were assumed to cause movement towards the left by immobile members of the non-manual classes, and towards the right by immobile members of the manual classes. However, this paper's findings do not support these assumptions, and imply that contextual effects of class mobility are unlikely to be responsible for variations in levels of class voting across countries and periods.

\section{NOTE}

The author is affiliated to the Department of Sociology of the Utrecht University, the Netherlands. This paper was part of his (Nieuwbeerta 1995), written when he was afflliated to the Department of Sociology of the University of Nijmegen, the Netherlands, and financially supported by the Netherlands Organization for Scientific Research (NWO Grants 500-179-001) The author wishes to thank Jan van Deth, Marry Duffy, Robert Erikson, John Goldthorpe, Nan Dirk de Graaf, Anthony Heath, Mike Hout and Wout Ultee for their detailed comments and suggestions. and Harry Ganzeboom for providing many datasets. Direct all correspondence to Paul Nieuwbeerta, Department of Sociology, Utrecht University, Heidelberglaan 1, 3564 CS Utrecht, The Netherlands. E-mail: socw68@ifswxl.fsw.ruu.nl. References to the studles and data sources can be obtained from the author as: P. Nieuwbeerta \& H.B.G. Ganzeboom, codebook International Socia Mobility and Politics-file.

\section{REFERENCES}

Abramson, P.R. (1972). Intergenerational Social Mobility and Partisan Choice. American Political Science Review, 66: 1291-1294.

Abramson, P.R., \& C. Books (1971). Social Mobility and Political Attitudes: A Study of Intergenerational Mobllity among Young British Men. Comparative Politics, 3: 403-428.

Alford, R. (1963). Party and Society: The Anglo-American Democracies. Westport: Greenwood Press.

Barber, J.A. (1970). Social Mobility and Voting Behavior. Chicago: Rand McNally.

Bartolini, S., \& P. Mair (1990). Identity, Competition and Electoral Availability: The Stabilisation of European Electorates, 1885-1985. Cambridge: Cambridge University Press.

Blau, P.M., \& O.D. Duncan (1967). The American Occupational Structure. New York: Free Press.

Clifford, P., \& A. Heath (1993). The Political Consequences of Social Mobility. Journal of the Royal Statistical Society, 156: 1-11.

De Graaf, N.D., P. Nieuwbeerta \& A. Heath (1995). Class Mobility and Political Preference: Individual and Contextual Effects. American Journal of Sociology, 100: 997-1027.

De Graaf, N.D., \& W. Ultee (1987). Intergenerationele Mobilitelt en Politieke Verhoudingen. Acta Politica, 22: 3-37.

De Graaf, N.D., \& W. Ultee (1990). Individual Preferences, Social Mobility and Electoral Outcomes. Electoral Studies, 9: 109-132.

Erikson, R., \& J.H. Goldthorpe (1992). The Constant Flux: A Study of Class Mobility in Industrial Societies. Oxford: Clarendon Press.

Erikson, R., J. Goldthorpe, \& J. Portocarrero (1979). Intergenerational Class Mobility in Three Western European Societies: England, France and Sweden. British Journal of Sociology, 30: $415-441$.

Evans, G., A. Heath \& C. Payne (1991). Modelling Trends in the Class/Party Relationship, 1964-1987. Electoral Studies, 10: 99-117. 
Franklin, M.N., T. Mackie, H. Valen et al. (1992). Electoral Change: Responses to Evolving Social and Attitudinal Structures in Western Countries. Cambridge: Cambridge University Press.

Ganzeboom, H.B.G., R. Luijkx \& D.J. Treiman (1989) Intergenerational Class Mobility in Comparative Perspective. Research in Social Stratification and Mobility, 8: 3-84.

Goldthorpe, J.H. (with C. Llewellyn, \& C. Payne) (1986). Social Mobility and Class Structure in Modern Britain (second edition). Oxford: Clarendon Press.

Goldthorpe, J.H., C. Payne \& C. Llewellyn (1978) Trends in Class Mobility. Sociology, 12: 441-468.

Heath, A., J. Curtice, R, Jowell, G. Evans, J. Field \& S. Witherspoon (1991). Understanding Political Change: The British Voter, 1964-1987. Oxford: Pergamon Press.

Heath, A., G. Evans \& C. Payne (1995). Modelling the Class/Party Relationship in Britain, 1964-92. Joumal of the Royal Statistics Society (forthcoming).

Heath, A., R. Jowell \& J. Curtice (1985). How Britain Votes. Oxford: Pergamon Press.

ILO (International Labour Office) (1969). International Standard Classification of Occupations (revised edition). Geneva: International Labour Office.

Lipset, S.M. (1960). Political Man: The Soctal Bases of Polttics. London: Heinemann.

Mackie, T.T., \& R. Rose (1991). The International Almanac of Electoral History (fully revised third edition). London: Macmillan.

Nieuwbeerta, P. (1995). The Democratic Class Struggle in Twenty Countries, 1945-1990. Amsterdam: Thesis Publishers.

Nieuwbeerta, P. (1996). The Democratic class struggle in Postindustrial societies: Class voting in twenty countries, 1945-1990. Acta Sociologica (forthcoming).

Nieuwbeerta, P., \& H.B.G. Ganzeboom (1995). International Social Mobility and Politics Flle: Documentation of a Dataset of National Surveys Held in Sixteen Countries, 1956-1990. Amsterdam: Steinmetz Archive.
Nieuwbeerta, P., \& N.D. de Graaf (1993). Intergenerational Class Mobility and Political Preference in the Netherlands between 1970 and 1986. Netherlands Journal of Soctal Sciences, 29: 28-45.

Parkin. F. (1971). Class Inequality and Political Order: Social Stratification in Capitalist and Communist Societies. London: Palladin Books.

Thorburn, P.J. (1979). Party, Class and Mobility: The Political Preferences of Men in England and Wales. Ph.D. dissertation. Ann Arbor: University of Michigan.

Weakliem, D.L. (1992). Does Soclal Mobility Affect Political Behavior? European Sociological Review, 8: 153-165. 
p. 62 - Bulletin de Methodologie Sociologique (59 rue Pouchet. F 75017 Paris), June 1996, N. 51

Table 1. Social class scheme: EGP categories

\begin{tabular}{|c|c|c|}
\hline Titie & Code & Description \\
\hline Service class & I.II & $\begin{array}{l}\text { Large proprietors; professionais, administrators and managers; } \\
\text { higher-grade technicians; supervisors of nonmanual workers. }\end{array}$ \\
\hline Routine nonmanual class & III & $\begin{array}{l}\text { Routine nonmanual employees in administration and commerce; } \\
\text { sajes personnei; other rank-and-file service workers. }\end{array}$ \\
\hline Petty bourgeoisie & IVa.b & Small proprietors and artisans, with and without employees. \\
\hline Farmers & IVc & $\begin{array}{l}\text { Farmers, smaliholders and other self-empioyed workers in pri- } \\
\text { mary production. }\end{array}$ \\
\hline Skilled workers & $\mathrm{V}, \mathrm{VI}$ & $\begin{array}{l}\text { Lower-grade technicians; supervisors of manual workers; } \\
\text { skilled manual workers. }\end{array}$ \\
\hline Nonskilled workers & VIla & Semi- and unskilled, nonagricultural manual workers. \\
\hline Agricultural labourers & vilib & Agricultural and other workers in primary production. \\
\hline
\end{tabular}

Tabje 2. Parameter estimates of multi-level models: the effects of inflow and outflow mobility on the left-wing voting behaviour of immobile class members

\begin{tabular}{|c|c|c|c|c|c|c|}
\hline & \multicolumn{2}{|c|}{ Model A } & \multicolumn{2}{|c|}{ Model B } & \multicolumn{2}{|c|}{ Model C } \\
\hline & Parameter & s.e. & Parameter & s.e & Parameter & s.e. \\
\hline \multicolumn{7}{|l|}{ Fixed effects } \\
\hline $\begin{array}{l}\text { Individual level } \\
\text { Intercept }\end{array}$ & -0.458 & 0.100 & -0.457 & 0.100 & -0.458 & 0.100 \\
\hline $\begin{array}{l}\text { Year level } \\
\text { inflow * in-weight } \\
\text { outtlow * out-weight }\end{array}$ & 0.004 & $\begin{array}{l}0.006 \\
-\end{array}$ & .001 & 0.007 & $\begin{array}{r}0.005 \\
.0 .002\end{array}$ & $\begin{array}{l}0.006 \\
0.007\end{array}$ \\
\hline \multicolumn{7}{|l|}{ Variance components } \\
\hline $\begin{array}{l}\text { lindividual level } \\
\text { Intercept }\end{array}$ & 1 & & 1 & & 1 & \\
\hline $\begin{array}{l}\text { Year level } \\
\text { Intercept }\end{array}$ & 0.093 & 0.015 & 0.094 & 0.015 & 0.093 & 0.015 \\
\hline $\begin{array}{l}\text { Country/class level } \\
\text { Intercept }\end{array}$ & 0.902 & 0.143 & 0.902 & 0.143 & 0.902 & 0.143 \\
\hline
\end{tabular}

Bulletin de Méthodologie Sociologique (59 rue Pouchet, F 75017 Paris), June 1996, N. 51 - p. 63

Table 3. Parameter estimates of multi-level modeis: effects of inflow and outflow mobility on left-wing voting behaviour of immobile class members, per class

\begin{tabular}{|c|c|c|c|c|c|c|}
\hline & \multicolumn{2}{|c|}{ Model A } & \multicolumn{2}{|c|}{ Modei B } & \multicolumn{2}{|c|}{ Model C } \\
\hline & Parameter & s.e. & Parasnerer & s.e. & Parameter & s.e. \\
\hline $\begin{array}{l}\text { Service class }(\mathrm{N}=5910 \text { ) } \\
\text { inflow " in-weight } \\
\text { outflow * out-weight }\end{array}$ & 0.017 & 0.021 & .0 .006 & 0.020 & $\begin{array}{r}0.017 \\
.0 .007\end{array}$ & $\begin{array}{l}0.021 \\
0.020\end{array}$ \\
\hline 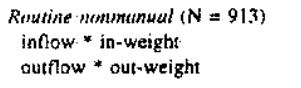 & 0.033 & 0.021 & 0.015 & $\overline{0.026}$ & $\begin{array}{r}0.033 \\
-0.000\end{array}$ & $\begin{array}{l}0.023 \\
0.028\end{array}$ \\
\hline $\begin{array}{l}\text { Pettr. brurgesisie ( } N=1062) \\
\text { inflow * in-weight } \\
\text { oufflow * oul-weight }\end{array}$ & -0.028 & 0.018 & $\begin{array}{c}- \\
-0.007\end{array}$ & 0.026 & $\begin{array}{r}-0.029 \\
0.003\end{array}$ & $\begin{array}{l}0.019 \\
0.027\end{array}$ \\
\hline $\begin{array}{l}\text { Furmiers ( } N=3098) \\
\text { inflow * in-weight } \\
\text { outflow" * out-weight }\end{array}$ & 0.017 & 0.019 & 0.010 & 0.021 & $\begin{array}{l}0.018 \\
0.012\end{array}$ & $\begin{array}{l}0.019 \\
0.020\end{array}$ \\
\hline $\begin{array}{l}\text { Skitled musuat }(N=6.144) \\
\text { inflow * in-weight } \\
\text { outfiow " cut-weight }\end{array}$ & 0.030 & 0.016 & 0.014 & 0.021 & $\begin{array}{l}0.008 \\
0.012\end{array}$ & $\begin{array}{l}0.017 \\
0.022\end{array}$ \\
\hline 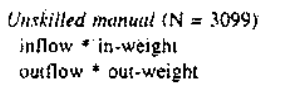 & 0.003 & 0.015 & .0 .035 & 0.020 & $\begin{array}{c}0.011 \\
-0.0 .39\end{array}$ & $\begin{array}{l}0.016 \\
0.021\end{array}$ \\
\hline 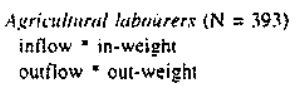 & 0.013 & 0.020 & 0.022 & 0.029 & $\frac{10.022}{0.031}$ & $\begin{array}{l}0.020 \\
0.030\end{array}$ \\
\hline
\end{tabular}

Table 4. Parameter estimates of multi-level models: the effects of levels of "pure" inflow and outflow mobility on the left-wing voting behaviour of immobile class members per class

\begin{tabular}{|c|c|c|c|c|c|c|}
\hline & \multicolumn{2}{|c|}{ Model D } & \multicolumn{2}{|c|}{ Model $\mathrm{E}$} & \multicolumn{2}{|c|}{ Model F } \\
\hline & Parameter & s.e. & Parameter & s.e. & Parameter & s.e. \\
\hline $\begin{array}{l}\text { Servite ethass }(N=5910) \\
\text { iallow } \\
\text { surfow }\end{array}$ & 0.018 & 0.011 & .0 .004 & $\overline{0.010}$ & $\begin{array}{r}0.019 \\
-0.007\end{array}$ & $\begin{array}{l}0.012 \\
0.010\end{array}$ \\
\hline $\begin{array}{l}\text { Rentine nemmunuali }\{\mathrm{N}=913\} \\
\text { inflow } \\
\text { outhow }\end{array}$ & 0.008 & 0.013 & 0.003 & $\dot{0.008}$ & $\begin{array}{r}0.010 \\
-0.002\end{array}$ & $\begin{array}{l}0.025 \\
0.016\end{array}$ \\
\hline 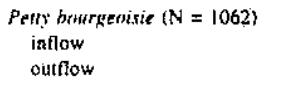 & -0.010 & 0.009 & 0.004 & 0.013 & $\begin{array}{r}0.010 \\
.0 .001\end{array}$ & $\begin{array}{l}0.010 \\
0.014\end{array}$ \\
\hline $\begin{array}{l}\text { Firmers (N:=3098) } \\
\text { ifflow } \\
\text { outflow }\end{array}$ & 0.009 & 0.009 & 0.009 & $\dot{0.011}$ & $\begin{array}{l}0.008 \\
0.007\end{array}$ & $\begin{array}{l}0.009 \\
0.011\end{array}$ \\
\hline $\begin{array}{l}\text { Skitled manual }(N=6144) \\
\text { infow } \\
\text { outflow }\end{array}$ & 0.001 & 0.009 & .0 .008 & $\dot{0.008}$ & $\begin{array}{r}0.004 \\
-0.0099\end{array}$ & $\begin{array}{l}0.010 \\
0.008\end{array}$ \\
\hline $\begin{array}{l}\text { Unskilled manual }(\mathrm{N}=3099) \\
\text { inflow } \\
\text { ourflow }\end{array}$ & -0.001 & 0.008 & .0009 & 0.009 & $\begin{array}{c}0.005 \\
-0.012\end{array}$ & $\begin{array}{l}0.009 \\
0.011\end{array}$ \\
\hline $\begin{array}{l}\text { Agriculiural lichurers }(N=393) \\
\text { infliow } \\
\text { outflow }\end{array}$ & 0.003 & 0.006 & 0.007 & 0.016 & $\begin{array}{l}0.003 \\
0.002\end{array}$ & $\begin{array}{l}0.008 \\
0.023\end{array}$ \\
\hline
\end{tabular}

